\title{
Fish oil at low dietary levels enhances physiological activity of sesamin to increase hepatic fatty acid oxidation in rats
}

\author{
Takashi Ide \\ Department of Food and Nutrition, Faculty of Human Life, Jumonji University, 2-1-28 Sugasawa, Niiza, Saitama 352-8510, Japan
}

(Received 26 March, 2012; Accepted 11 June, 2012; Published online 31 October, 2012)

\begin{abstract}
We previously demonstrated that a diet containing fish oil at a level of $80 \mathrm{~g} / \mathrm{kg}$ strongly stimulated the physiological activity of a sesame sesamin preparation containing sesamin and episesamin at equal amounts to increase hepatic fatty acid oxidation. This study was conducted to clarify whether fish oil at lower dietary levels enhances the physiological activity of sesamin to increase hepatic fatty acid oxidation. Rats were fed experimental diets supplemented with 0 or $2 \mathrm{~g}$ sesamin/kg, and containing 0,15 or $30 \mathrm{~g}$ fish oil/kg for 15 days. Among rats fed sesamin-free diets, diets containing 15 and $30 \mathrm{~g}$ fish oil/kg slightly increased the activity of enzymes involved in hepatic fatty acid oxidation. Sesamin increased these values irrespective of the presence or absence of fish oil in diets; however, the extent of the increase of many parameters was much greater in rats given fish oil-containing diets than in those fed a fish oil-free diet. Diets simultaneously containing sesamin and fish oil increased the gene expression of various peroxisomal fatty acid oxidation enzymes in a synergistic manner; but they were ineffective in causing a synergistic increase in mRNA levels of mitochondrial fatty acid oxidation enzymes. The extent of the synergistic increase in the activity of hepatic fatty acid oxidation enzymes and mRNA levels of the peroxisomal enzymes was indistinguishable between diets containing 15 and $30 \mathrm{~g}$ fish oil/kg and appeared comparable to that observed previously with a diet containing $80 \mathrm{~g}$ fish oil/kg.
\end{abstract}

Key Words: sesamin, fish oil, fatty acid oxidation, peroxisomes, gene expression

$\mathrm{S}$ esamin is one of the most abundant lignans in sesame seed, and is epimerized during acid-clay bleaching in the oilrefining process to form episesamin. ${ }^{(1)}$ Therefore, commercial sesamin preparations obtained as a byproduct of the oil-refining process contain sesamin and episesamin at about equivalent rates. We previously found that the sesamin preparation profoundly and dose-dependently increased the activity and gene expression of fatty acid oxidation enzymes in rat liver, presumably through the activation of peroxisome proliferator-activated receptor (PPAR) $\alpha .^{(2)}$ A later study showed that episesamin is more effective than sesamin in increasing the activity and gene expression of fatty acid oxidation enzymes. $^{(3)}$ It is well demonstrated that fish oil rich in eicosapentaenoic acid (EPA) and docosahexaenoic acid (DHA) also increases hepatic fatty acid oxidation, although the magnitude of the increase is much weaker with fish oil than with sesamin. ${ }^{(4-6)}$ We previously demonstrated that a diet simultaneously containing sesamin and fish oil at levels of 2 and $80 \mathrm{~g} / \mathrm{kg}$, respectively, increased the activity of many enzymes involved in hepatic fatty acid oxidation in a synergistic manner. ${ }^{(6)}$ We subsequently reported that diets simultaneously containing sesamin and highly purified either EPA or DHA in the form of ethyl esters added to experi- mental diets at a level of $20 \mathrm{~g} / \mathrm{kg}$ mimic the physiological activity of fish oil in enhancing the sesamin-dependent increase in hepatic fatty acid oxidation. (7) Analysis of the mRNA levels of various hepatic enzymes involved in fatty acid oxidation strongly indicated that up-regulation of the gene expression of peroxisomal enzymes is responsible for this effect. ${ }^{(6,7)}$ These observations indicate that $\mathrm{n}-3$ fatty acids abundant in fish oil not only increase hepatic fatty acid oxidation but also act as a co-activator of sesamin to enhance peroxisomal fatty acid oxidation; however, the dietary levels of fish oil $(80 \mathrm{~g} / \mathrm{kg})$ or EPA and DHA $(20 \mathrm{~g} / \mathrm{kg})$ employed in the previous studies were much higher than those expected in human diets. A nutritional survey conducted in 2005 in Japan (http://www.mhlw.go.jp/houdou/2006/05/h0508-1.html) indicated that the fat level is $130-140 \mathrm{~g} / \mathrm{kg}$ diet and one-tenth was derived from fish in the human diet. Also, the food composition table (http://fooddb.jp/) indicated that oils from edible fish contain $200 \mathrm{~g} / \mathrm{kg}$ of n-3 fatty acids on average. This means that fish oil and derived n-3 fatty acids comprise 13-14 g/ $\mathrm{kg}$ and 2-3 g/ kg, respectively, in the typical Japanese diet; therefore, it is important to clarify the impact of fish oil to enhance the physiological activity of sesamin to increase hepatic fatty acid oxidation at dietary levels lower than those employed previously. We found in the present study that fish oil at a dietary level as low as $15 \mathrm{~g} / \mathrm{kg}$ strongly enhanced the physiological activity of sesamin to increase hepatic fatty acid oxidation.

\section{Materials and Methods}

Animals and diets. Male Sprague-Dawley rats obtained from Charles River Japan (Kanagawa, Japan), at 4 weeks of age were housed individually in animal cages in a room with controlled temperature $\left(20-22^{\circ} \mathrm{C}\right.$, humidity $(55-65 \%)$, and lighting (lights on from 6:00 to 18:00 h), and fed a commercial diet (Type NMF; Oriental Yeast Co., Tokyo, Japan). After 7 day of acclimatization, rats were fed purified experimental diets supplemented with 0 or $2 \mathrm{~g}$ sesamin (1:1 mixture of sesamin and episesamin; Takemoto Oil Co., Aichi, Japan)/kg, and containing 0,15 or $30 \mathrm{~g}$ fish oil $/ \mathrm{kg}$ for 15 days. Dietary fat levels were adjusted to be $100 \mathrm{~g} / \mathrm{kg}$ by adding palm oil. The basal composition of the purified experimental diets was (in $\mathrm{g} / \mathrm{kg}$ ): casein, 200; dietary fat, 100 (palm and fish oils); corn starch, 150; cellulose, 20; mineral mixture, ${ }^{(8)} 35$; vitamin mixture, ${ }^{(8)} 10$; L-cystine, 3; choline bitartrate, 2.5 and sucrose to $1 \mathrm{~kg}$. Sesamin was added to experimental diets in lieu of sucrose. Palm and fish oils were the gifts from NOF Corp., Tokyo, Japan. Animals had free access to the diets and water during the experimental period. Fatty acid compositions of dietary fats were

To whom correspondence should be addressed.

E-mail: t-ide@jumonji-u.ac.jp 
(in $\mathrm{g} / 100 \mathrm{~g}$ fatty acids): $14: 0,2.68 ; 16: 0,15.0 ; 16: 1,5.72 ; 18: 0$, $3.66 ; 18: 1,21.8 ; 18: 2,1.57 ; 18: 3$ (n-3), $0.88 ; 20: 3$ (n-6), $0.21 ; 20: 4$ (n-6), 2.45; 20:5 (n-3), 10.1; 22:4 (n-6), 0.33; 22:5 (n-6), 1.45; $22: 5(\mathrm{n}-3), 1.98 ; 22: 6(\mathrm{n}-3), 32.2$ for fish oil and $14: 0,0.94 ; 16: 0$, $44.2,16: 1,0.19 ; 18: 0,4.43 ; 18: 1,40.4 ; 18: 2,9.62 ; 18: 3$ (n-3), 0.22 for palm oil, respectively. This study was approved by the review board of animal ethics of our university and we followed the university's guidelines for the care and use of laboratory animals.

Enzyme assays. Upon termination of the experiments, animals were anesthetized using diethyl ether and killed by bleeding from the inferior vena cava, after which livers were excised immediately. About $2 \mathrm{~g}$ of each liver was homogenized with $15 \mathrm{ml}$ of $0.25 \mathrm{~mol} / \mathrm{l}$ sucrose containing $1 \mathrm{mmol} / 1 \mathrm{EDTA}$ and $3 \mathrm{mmol} / \mathrm{l}$ Tris- $\mathrm{HCl}(\mathrm{pH} 7.2)$. Activity levels of various hepatic fatty acid oxidation enzymes were measured spectrophotometrically using the whole liver homogenate as an enzyme source, as detailed previously. ${ }^{(2,4,9)}$ The peroxisomal palmitoyl-CoA oxidation rate, and acyl-CoA oxidase and carnitine palmitoyltransferase activities were measured using palmitoyl-CoA as a substrate. We used trans-2-octenoyl-CoA, 3-ketooctanoyl-CoA and sorboyl-CoA as substrates in assaying enoyl-CoA hydratase, 3-keotacyl-CoA thiolase and 2,4-dienoyl-CoA reductase activities, respectively.

RNA analysis. RNA in liver was extracted, and mRNA abundance was analyzed by quantitative real-time PCR as detailed elsewhere. ${ }^{(10)}$ The nucleotide sequences of primers and probes designed using Primer Express Software (Applied Biosystems) have been reported previously. ${ }^{(1)}$ mRNA abundance was calculated as a ratio to the $\beta$-actin level in each cDNA sample and expressed as a fold change, assigning the value in rats fed a diet free of fish oil and sesamin as 1 .

Analyses of lipids and lignans. Serum triacylglycerol, cholesterol, phospholipid, and free fatty acid concentrations were measured using commercial enzyme kits (Wako Pure Chem. Ind. Ltd., Osaka, Japan). Concentrations of sesamin and episesamin in the serum and liver were analyzed by HPLC as detailed previously.(6) Hepatic concentrations of EPA and DHA were analyzed by GLC using a FAMEWAX ${ }^{\mathrm{TM}}$ column $(30 \mathrm{~m} \times 0.25 \mathrm{~mm}$, Restek, PA) and heptadecanoic acid as an internal standard.

Statistical analysis. Microsoft Excel add-in software (Excel Statistics 2010, Social Survey Research Information Co., Tokyo, Japan) was used for the statistical analysis. The data for two-way classification were analyzed by two-way ANOVA to establish the effect of fish oil and sesamin or any interaction between these two factors. If no significant interaction existed, Tukey's post-hoc test was conducted to detect differential effects of diets containing varying amounts of fish oil. When the interaction was significant, the data were reanalyzed with one-way ANOVA and the post-hoc test. The data for one-way classification were analyzed using oneway ANOVA and the post-hoc test. Differences were considered significant when $p<0.05$.

\section{Results}

Neither fish oil nor sesamin affected food intake (19.5-20.7 $\mathrm{g} /$ day) or growth (127-133 g/15 days) of rats. Dietary fish oil did not affect the liver weight of rats, but sesamin significantly increased this parameter among the animals fed diets containing different amounts of fish oil $(5.47 \pm 0.13,5.18 \pm 0.12$ and $5.34 \pm$ $0.15 \mathrm{~g} / 100 \mathrm{~g}$ body weight for rats fed sesamin-free diets containing 0,15 and $30 \mathrm{~g} / \mathrm{kg}$ fish oil, and $6.05 \pm 0.06,6.33 \pm 0.16$ and $6.28 \pm$ $0.18 \mathrm{~g} / 100 \mathrm{~g}$ body weight for the animals fed $2 \mathrm{~g} / \mathrm{kg}$ sesamin diets containing 0,15 and $30 \mathrm{~g}$ fish oil $/ \mathrm{kg}$, respectively).

Among rats fed sesamin-free diets, a diet containing $15 \mathrm{~g}$ fish oil $/ \mathrm{kg}$ caused $25-90 \%$ increases in the activity of enzymes involved in hepatic fatty acid oxidation (Fig. 1A). A diet containing $30 \mathrm{~g}$ fish oil $/ \mathrm{kg}$ caused greater increases in these parameters (40-147\% increases), although the differences between rats fed diets containing 15 and $30 \mathrm{~g}$ fish oil $/ \mathrm{kg}$ were not always significant. Dietary sesamin greatly increased these parameters in both rats fed fish oil-free and -containing diets; however, the extent of the increase in many of the parameters was apparently greater in rats given fish oil-containing diets than in animals fed a fish oil-free diet, and two-way ANOVA revealed significant interactions between the two dietary factors, that is, fish oil and sesamin, in affecting these parameters, except for 2,4-dienoyl$\mathrm{CoA}$ reductase. To clarify the interaction of fish oil and sesamin, sesamin-dependent increases in enzyme activity were calculated by subtracting the value in rats fed a sesamin-free diet containing different amounts of fish oil from the corresponding value in animals fed a sesamin diet containing the respective levels of fish oil. Values are expressed as percentages assigning the value in rats fed a fish oil-free diet containing sesamin as 100, and are shown in Fig. 1B. Fish oil markedly enhanced the physiological activity of sesamin to increase the peroxisomal palmitoyl-CoA oxidation rate and the activity of acyl-CoA oxidase and carnitine palmitoyltransferase. The sesamin-dependent increases of these parameters were more than 2 times higher in rats fed diets simultaneously containing fish and sesamin than in animals fed a diet containing sesamin alone; however, these values were comparable between rats fed the diets simultaneously containing sesamin, and 15 and $30 \mathrm{~g}$ fish oil $/ \mathrm{kg}$. Although the fish oil-dependent change in this parameter was weaker for 3-ketoacyl-CoA thiolase, fish oil at 15 and $30 \mathrm{~g} / \mathrm{kg}$ diet also significantly increased the value. Also, fish oil added to the sesamin-containing diet at 30 but not at $15 \mathrm{~g} / \mathrm{kg}$ significantly enhanced the physiological activity of sesamin to increase the activity of enoyl-CoA hydratase; however, fish oil rather attenuated sesamin-dependent changes in the activity of 2,4-dienoyl-CoA reductase.

Fig. 2A shows mRNA levels of peroxisomal enzymes involved in fatty acid oxidation and peroxin- $11 \alpha$, a peroxisomal membrane protein. ${ }^{(12)}$ Among the various peroxisomal proteins, a sesaminfree diet containing fish oil at a $15 \mathrm{~g} / \mathrm{kg}$ dietary level compared to a control diet significantly increased the mRNA levels of carnitine octanoyltransferase and acyl-CoA oxidase 1, but not of 3-ketoacylCoA thiolase and peroxin- $11 \alpha$, while fish oil at a $30 \mathrm{~g} / \mathrm{kg}$ dietary level significantly increased the mRNA levels of all these peroxisomal proteins. Sesamin increased the mRNA levels of peroxisomal proteins both in rats fed a fish oil-free and fish oilcontaining diets. The extent of the increase was apparently greater in the latter than the former. In fact, two-way ANOVA showed significant interactions between sesamin and fish oil in affecting mRNA levels of these peroxisomal proteins. Sesamin-dependent increases in mRNA levels of carnitine octanoyltransferase were about 3-times higher in rats fed diets containing 15 and $30 \mathrm{~g}$ fish oil $/ \mathrm{kg}$ than in animals fed a fish oil-free diet (Fig. 2B). Also, the parameters for the other peroxisomal proteins were about 2-times higher in the groups of animals fed fish oil than in those fed a fish oil-free diet; therefore, it is apparent that fish oil strongly enhanced the physiological activity of sesamin to increase the expression of these genes. Consistent with the results observed on enzyme activity, differences in the dietary levels of fish oil did not affect the magnitude of the response.

The previous study ${ }^{(6)}$ showed that a diet containing $80 \mathrm{~g}$ fish oil/kg strongly enhanced the physiological activity of sesamin to increase mRNA levels of various peroxisomal fatty acid oxidation enzymes, but not of mitochondrial enzymes. The situation appeared to be the same in this study where fish oil was added to experimental diets at lower levels (Table 1). Two-way ANOVA revealed that both fish oil and sesamin increased mRNA levels of various hepatic mitochondrial enzymes involved in $\beta$-oxidation (carnitine palmitoyltransferase 2, trifunctional enzyme subunit $\alpha$ and $\beta$, and 3-ketoacyl-CoA thiolase), an auxiliary pathway for $\beta$-oxidation (2,4-dienoyl-CoA reductase and $\Delta^{3}, \Delta^{2}$-enoyl-CoA isomerase 1) and ketogenesis (3-hydroxy-3-methylglutaryl-CoA synthase); however, the interactions of sesamin and fish oil in affecting these parameters except for $\Delta^{3}, \Delta^{2}$-enoyl-CoA isomerase 1 


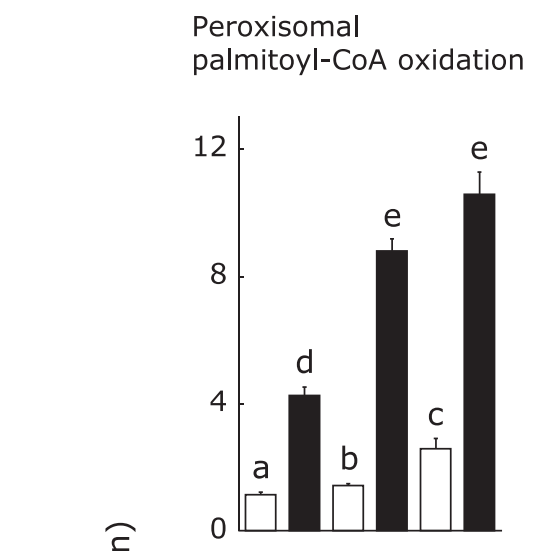

\section{Acyl-CoA \\ oxidase}

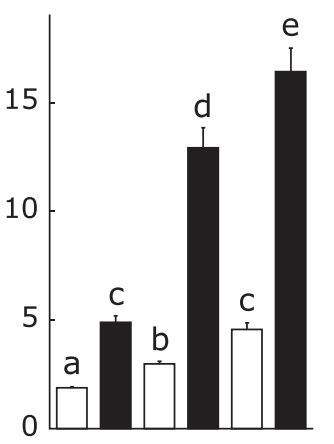

Carnitine

palmitoyltransferase $\times 10^{3}$

Enoyl-CoA

hydratase

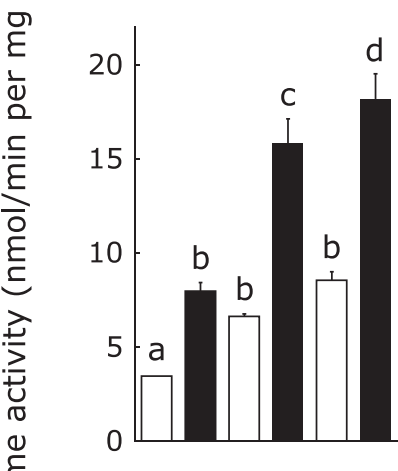

츨

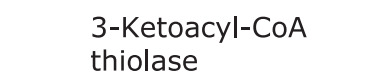

Sesamin

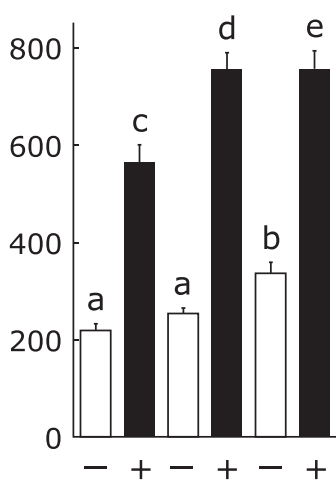

Fish oil $(\mathrm{g} / \mathrm{kg}) \quad 0 \quad 15 \quad 30$

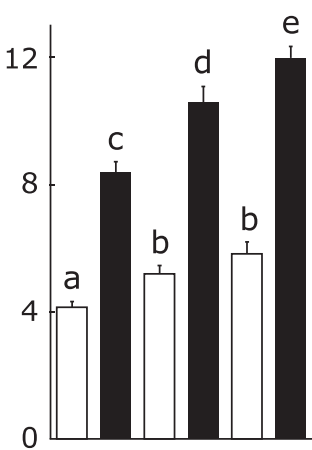

2,4-Dienoyl-CoA reductase

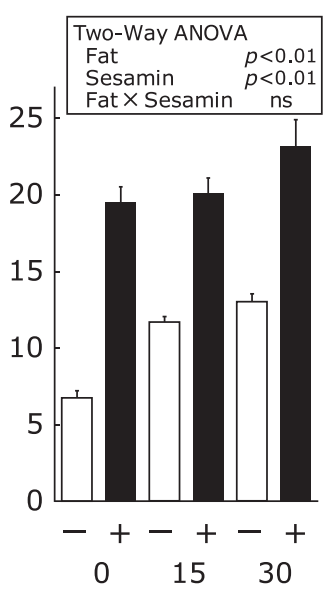

Sesamin-dependent

increase in enzyme activity
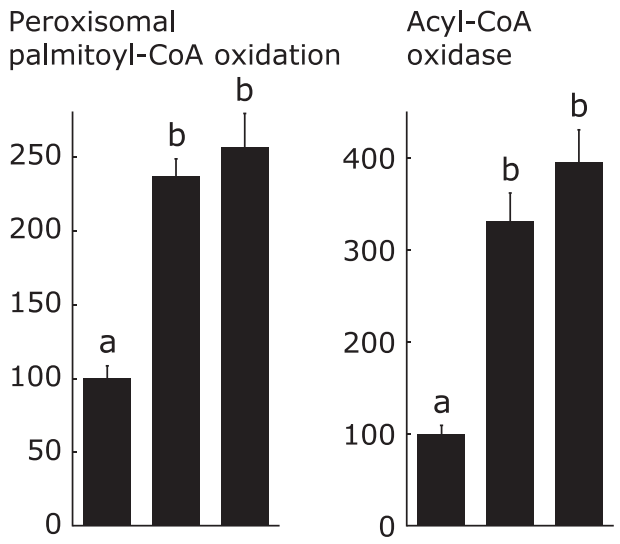

Carnitine

․ palmitoyltransferase

Enoyl-CoA

hydratase
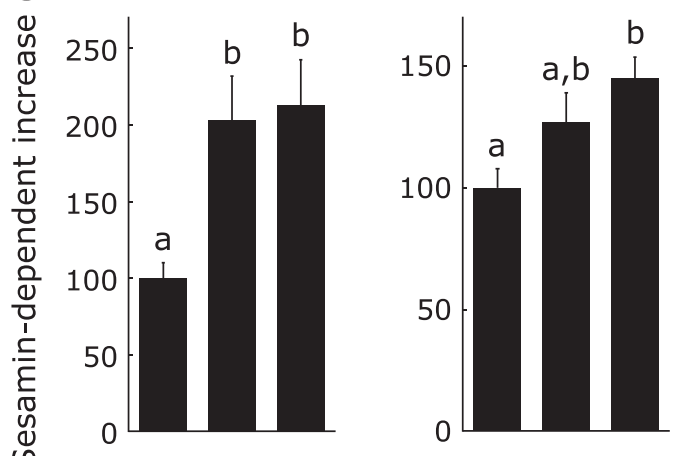

3-Ketoacyl-CoA thiolase

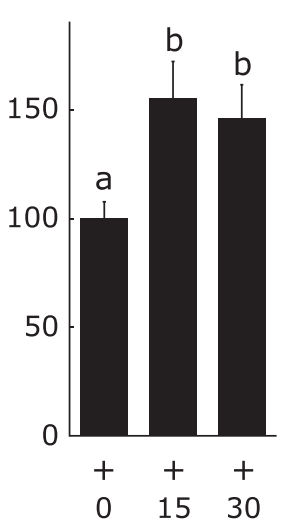

2,4-Dienoyl-CoA reductase

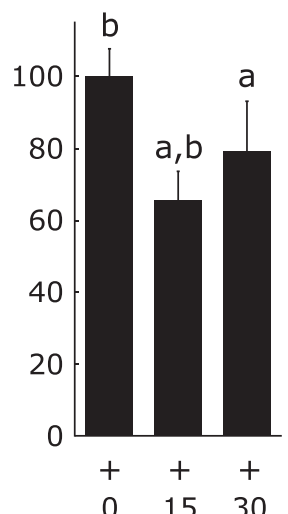

Fig. 1. Interaction of dietary fish oil (15 and $30 \mathrm{~g} / \mathrm{kg})$ and sesamin $(2 \mathrm{~g} / \mathrm{kg})$ in affecting the activity of enzymes involved in hepatic fatty acid oxidation. The activity of hepatic fatty acid oxidation enzymes was analyzed using total homogenate as an enzyme source (A). Sesamin-dependent increases in enzyme activity in rats fed diets containing different amounts of fish oil were calculated and expressed as percentages, assigning the value in the animals fed a fish oil-free diet containing $2 \mathrm{~g}$ sesamin/kg as 100 (B). Values are the means \pm SE of seven rats. Two-way ANOVA revealed significant interactions between the two dietary factors, that is, fish oil and sesamin, in affecting the activities of various enzymes, except for 2,4dienoyl-CoA reductase (A); therefore, these values were reanalyzed by one-way ANOVA and Tukey's post-hoc test. The values for sesamin-dependent increases in enzyme activity were analyzed by one-way ANOVA and the post-hoc test (B). a,b,c,d,e Means without a common letter differ, $p<0.05$.

were not significant. Also, the sesamin-dependent increases in these values were all comparable except for one instance $\left(\Delta^{3}, \Delta^{2}-\right.$ enoyl-CoA isomerase $1 \mathrm{mRNA}$ level in rats fed a diet containing $30 \mathrm{~g}$ fish oil $/ \mathrm{kg}$ ). Fish oil and sesamin also significantly increased the mRNA level of microsomal cytochrome P-450 4al involved in $\omega$-oxidation of fatty acids; however, fish oil did not affect the sesamin-dependent increase in this parameter.

Fish oil at 15 and $30 \mathrm{~g} / \mathrm{kg}$ dietary levels significantly reduced 
Carnitine

octanoyltransferase

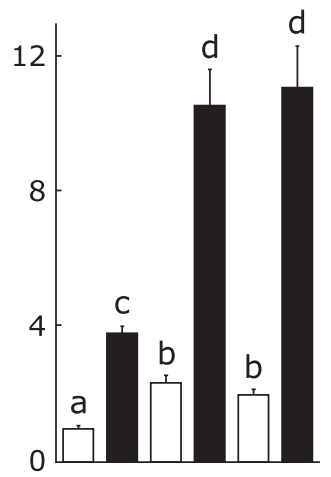

Acyl-CoA

oxidase 1

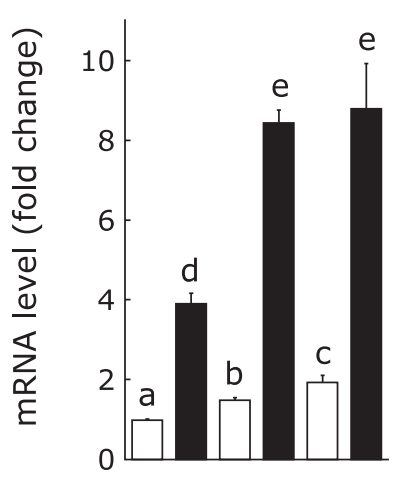

Peroxisomal

3-ketoacyl-CoA thiolase

12

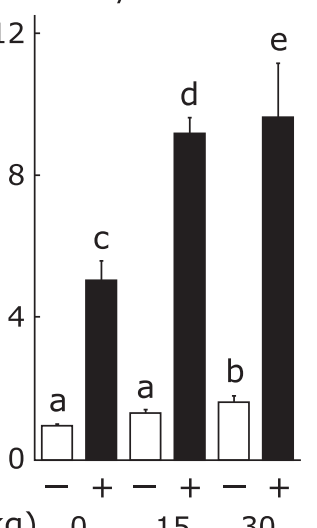

Peroxisomal

bifunctional enzyme
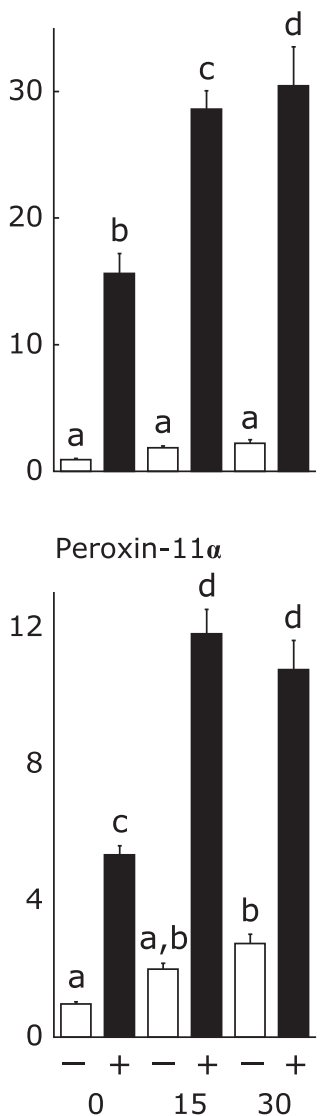

Carnitine

octanoyltransferase
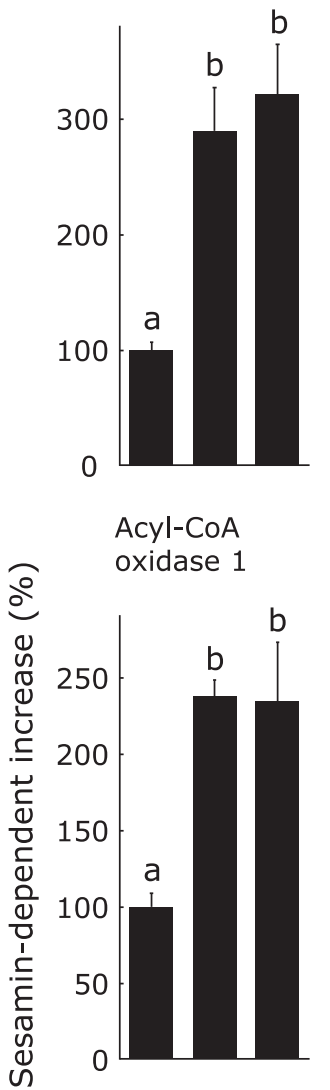

Peroxisomal

bifunctional enzyme

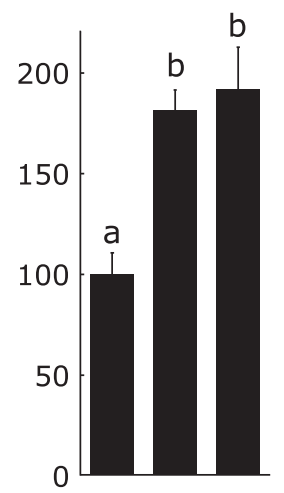

Peroxisomal

3-ketoacyl-CoA thiolase

Peroxin-11 $\alpha$

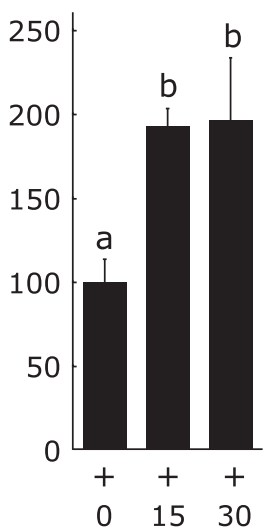

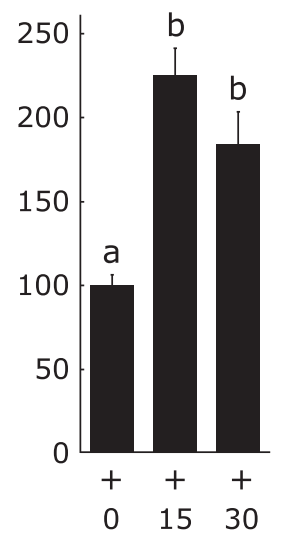

Fig. 2. Interaction of dietary fish oil ( 15 and $30 \mathrm{~g} / \mathrm{kg})$ and sesamin $(2 \mathrm{~g} / \mathrm{kg})$ in affecting mRNA levels of peroxisomal enzymes involved in hepatic fatty acid oxidation, and peroxin-11 $\alpha$. Hepatic RNA was extracted and mRNA abundance was analyzed by quantitative real-time PCR (A). Values are expressed as a fold change, assigning the value in rats fed a diet free of fish oil and sesamin as 1 . Sesamin-dependent increases in mRNA level in rats fed diets containing different amounts of fish oil were calculated and expressed as percentages assigning the value in the animals fed a fish oil-free diet containing $2 \mathrm{~g}$ sesamin/kg as 100 (B). Values are the means \pm SE of seven rats. Two-way ANOVA revealed significant interactions between the two dietary factors, that is, fish oil and sesamin, in affecting the mRNA levels of various peroxisomal proteins (A); therefore, these values were reanalyzed by one-way ANOVA and Tukey's post-hoc test. Values for sesamin-dependent increases in enzyme activity were analyzed by one-way ANOVA and the post-hoc test (B). a,b,c,d Means without a common letter differ, $p<0.05$.

serum concentrations of triacylglycerol and cholesterol among rats fed sesamin-free diets (Table 2); however, dose-dependent effects of fish oil on these parameters were not observed. Sesamin significantly reduced these parameters in rats given diets con- taining 0 and $30 \mathrm{~g}$ fish oil $/ \mathrm{kg}$. As a result, serum concentrations of triacylglycerol and cholesterol became very low in rats fed a diet containing $30 \mathrm{~g}$ fish oil $/ \mathrm{kg}$ and sesamin in combination; however, significant sesamin-dependent changes in these para- 
Table 1. Interaction of dietary fish oil (15 and $30 \mathrm{~g} / \mathrm{kg})$ and sesamin $(2 \mathrm{~g} / \mathrm{kg})$ in affecting mRNA levels of mitochondrial enzymes involved in hepatic fatty acid oxidation and microsomal cytochrome P-450 4a1

\begin{tabular}{|c|c|c|c|c|c|c|c|c|c|c|c|c|}
\hline \multirow[b]{2}{*}{ mRNA level (fold change) } & \multicolumn{6}{|c|}{ Dietary fats and sesamin } & \multicolumn{3}{|c|}{ Two-way ANOVA ( $p$ value) } & \multicolumn{3}{|c|}{ Post-hoc analysis ( $p$ value) } \\
\hline & $\begin{array}{c}100 \mathrm{~g} \mathrm{Palm} \\
\mathrm{oil} / \mathrm{kg}\end{array}$ & $\begin{array}{c}100 \mathrm{~g} \mathrm{Palm} \\
\text { oil } / \mathrm{kg} \\
+ \\
2 \mathrm{~g} \\
\text { sesamin } / \mathrm{kg}\end{array}$ & $\begin{array}{c}85 \mathrm{~g} \mathrm{Palm} \\
\text { oil/kg } \\
+ \\
15 \mathrm{~g} \text { fish } \\
\text { oil } / \mathrm{kg}\end{array}$ & $\begin{array}{c}85 \mathrm{~g} \mathrm{Palm} \\
\text { oil/kg } \\
+ \\
15 \mathrm{~g} \text { fish } \\
\text { oil } / \mathrm{kg}+ \\
2 \mathrm{~g} \\
\text { sesamin } / \mathrm{kg}\end{array}$ & $\begin{array}{c}70 \mathrm{~g} \mathrm{Palm} \\
\text { oil/kg } \\
+ \\
30 \mathrm{~g} \mathrm{Fish} \\
\mathrm{oil} / \mathrm{kg}\end{array}$ & $\begin{array}{c}70 \mathrm{~g} \mathrm{Palm} \\
\mathrm{oil} / \mathrm{kg} \\
+ \\
30 \mathrm{~g} \text { Fish } \\
\text { oil/kg }+ \\
2 \mathrm{~g} \\
\text { sesamin } / \mathrm{kg} \\
\end{array}$ & Fish oil & Sesamin & $\begin{array}{c}\text { Fish oil } \\
\times \\
\text { Sesamin }\end{array}$ & $\begin{array}{c}\text { Fish } \\
\text { oil-free } \\
\text { vs } \\
15 \mathrm{~g} \text { Fish } \\
\text { oil/kg }\end{array}$ & $\begin{array}{c}\text { Fish } \\
\text { oil-free } \\
\text { vs } \\
30 \mathrm{~g} \mathrm{Fish} \\
\text { oil/kg }\end{array}$ & $\begin{array}{c}15 \mathrm{~g} \text { Fish } \\
\mathrm{oil} / \mathrm{kg} \\
\mathrm{vs} \\
30 \mathrm{~g} \mathrm{Fish} \\
\mathrm{oil} / \mathrm{kg}\end{array}$ \\
\hline \multicolumn{13}{|l|}{ Mitochondrial enzymes } \\
\hline Carnitine palmitoyltransferase 2 & $1.00 \pm 0.05$ & $\begin{array}{c}2.62 \pm 0.14 \\
(100 \pm 9)\end{array}$ & $1.29 \pm 0.04$ & $\begin{array}{c}2.95 \pm 0.18 \\
(102 \pm 11)\end{array}$ & $1.51 \pm 0.12$ & $\begin{array}{l}2.86 \pm 0.38 \\
(82.7 \pm 23)\end{array}$ & ns & $<0.01$ & ns & - & - & - \\
\hline Trifunctional enzymes subunit $\alpha$ & $1.00 \pm 0.04$ & $\begin{array}{c}2.56 \pm 0.11 \\
(100 \pm 7)\end{array}$ & $1.42 \pm 0.06$ & $\begin{array}{c}3.08 \pm 0.09 \\
(106 \pm 6)\end{array}$ & $1.65 \pm 0.09$ & $\begin{array}{c}2.94 \pm 0.18 \\
(83.1 \pm 11.5)\end{array}$ & $<0.01$ & $<0.01$ & ns & $<0.01$ & $<0.01$ & ns \\
\hline Trifunctional enzymes subunit $\beta$ & $1.00 \pm 0.03$ & $\begin{array}{c}3.27 \pm 0.16 \\
(100 \pm 7)\end{array}$ & $1.48 \pm 0.07$ & $\begin{array}{c}3.78 \pm 0.15 \\
(101 \pm 7)\end{array}$ & $1.89 \pm 0.15$ & $\begin{array}{c}3.99 \pm 0.42 \\
(92.6 \pm 18.6)\end{array}$ & $<0.01$ & $<0.01$ & ns & ns & $<0.01$ & ns \\
\hline Mitochondrial 3-ketoacyl-CoA thiolase & $1.00 \pm 0.02$ & $\begin{array}{c}2.63 \pm 0.11 \\
(100 \pm 7)\end{array}$ & $1.54 \pm 0.06$ & $\begin{array}{c}3.58 \pm 0.22 \\
(126 \pm 13)\end{array}$ & $1.65 \pm 0.10$ & $\begin{array}{c}3.12 \pm 0.33 \\
(90.6 \pm 20.1)\end{array}$ & $<0.01$ & $<0.01$ & ns & $<0.01$ & $<0.01$ & ns \\
\hline 3-Hydroxy-3-methylglutaryl-CoA synthase & $1.00 \pm 0.03$ & $\begin{array}{c}2.41 \pm 0.09 \\
(100 \pm 6)\end{array}$ & $1.57 \pm 0.05$ & $\begin{array}{c}3.31 \pm 0.08 \\
(123 \pm 6)\end{array}$ & $1.74 \pm 0.10$ & $\begin{array}{c}3.16 \pm 0.20 \\
(101 \pm 14)\end{array}$ & $<0.01$ & $<0.01$ & ns & $<0.01$ & $<0.01$ & ns \\
\hline 2,4-Dienoyl-CoA reductase & $1.00 \pm 0.07$ & $\begin{array}{c}5.67 \pm 0.37 \\
(100 \pm 8)\end{array}$ & $2.57 \pm 0.15$ & $\begin{array}{c}8.07 \pm 0.34 \\
(118 \pm 7)\end{array}$ & $3.72 \pm 0.31$ & $\begin{array}{c}8.14 \pm 0.78 \\
(94.6 \pm 16.8)\end{array}$ & $<0.01$ & $<0.01$ & ns & $<0.01$ & $<0.01$ & ns \\
\hline$\Delta^{3}, \Delta^{2}$-Enoyl-CoA isomerase & $1.00 \pm 0.04^{\mathrm{a}}$ & $\begin{array}{c}9.14 \pm 0.57^{c} \\
(100 \pm 7)\end{array}$ & $2.08 \pm 0.16^{\mathrm{a}, \mathrm{b}}$ & $\begin{array}{c}12.9 \pm 0.8^{d} \\
(133 \pm 9)\end{array}$ & $3.43 \pm 0.36^{b}$ & $\begin{array}{c}11.6 \pm 0.6^{d} \\
(100 \pm 7)\end{array}$ & $<0.01$ & $<0.01$ & $<0.01$ & - & - & - \\
\hline \multicolumn{13}{|l|}{ Microsomal enzyme } \\
\hline Cytochrome P-450 4a1 & $1.03 \pm 0.03^{\mathrm{a}}$ & $\begin{array}{c}5.70 \pm 0.26^{c} \\
(100 \pm 5)\end{array}$ & $1.56 \pm 0.05^{\mathrm{a}, \mathrm{b}}$ & $\begin{array}{c}7.59 \pm 0.32^{\mathrm{d}} \\
(128 \pm 7)\end{array}$ & $2.07 \pm 0.14^{b}$ & $\begin{array}{c}7.30 \pm 0.38^{\mathrm{d}} \\
(111 \pm 8)\end{array}$ & $<0.01$ & $<0.01$ & $<0.05$ & - & - & - \\
\hline
\end{tabular}

Values are the means \pm SE of 7 rats. a,b,c,d Means in a row with superscripts without a common letter differ, $p \leq 0.05$. Sesamin-dependent increases in mRNA levels were calculated and expressed as percentages assigning the value in the animals fed a fish oil-free diet containing $2 \mathrm{~g}$ sesamin/kg as 100 , and are shown in parentheses. ns: Not significant.

Table 2. Interaction of dietary fish oil (15 and $30 \mathrm{~g} / \mathrm{kg})$ and sesamin $(2 \mathrm{~g} / \mathrm{kg})$ in affecting serum lipid and lignan levels

\begin{tabular}{|c|c|c|c|c|c|c|c|c|c|c|c|c|}
\hline & \multicolumn{6}{|c|}{ Dietary fats and sesamin } & \multicolumn{3}{|c|}{ Two-way ANOVA ( $p$ value) } & \multicolumn{3}{|c|}{ Post-hoc analysis ( $p$ value) } \\
\hline & $\begin{array}{c}100 \mathrm{~g} \mathrm{Palm} \\
\text { oil } / \mathrm{kg}\end{array}$ & $\begin{array}{c}100 \mathrm{~g} \mathrm{Palm} \\
\text { oil } / \mathrm{kg} \\
+ \\
2 \mathrm{~g} \\
\text { sesamin } / \mathrm{kg}\end{array}$ & $\begin{array}{c}85 \mathrm{~g} \mathrm{Palm} \\
\mathrm{oil} / \mathrm{kg} \\
+ \\
15 \mathrm{~g} \text { fish } \\
\text { oil } / \mathrm{kg}\end{array}$ & $\begin{array}{c}85 \mathrm{~g} \mathrm{Palm} \\
\text { oil/kg } \\
+ \\
15 \mathrm{~g} \text { fish } \\
\text { oil } / \mathrm{kg}+ \\
2 \mathrm{~g} \\
\text { sesamin } / \mathrm{kg}\end{array}$ & $\begin{array}{c}70 \mathrm{~g} \mathrm{Palm} \\
\text { oil } / \mathrm{kg} \\
+ \\
30 \mathrm{~g} \mathrm{Fish} \\
\text { oil } / \mathrm{kg}\end{array}$ & $\begin{array}{c}70 \mathrm{~g} \mathrm{Palm} \\
\text { oil/kg } \\
+ \\
30 \mathrm{~g} \mathrm{Fish} \\
\mathrm{oil} / \mathrm{kg}+ \\
2 \mathrm{~g} \\
\text { sesamin } / \mathrm{kg}\end{array}$ & Fish oil & Sesamin & $\begin{array}{c}\text { Fish oil } \\
\quad \times \\
\text { Sesamin }\end{array}$ & $\begin{array}{c}\text { Fish } \\
\text { oil-free } \\
\text { vs } \\
15 \mathrm{~g} \mathrm{Fish} \\
\text { oil/kg }\end{array}$ & $\begin{array}{c}\text { Fish } \\
\text { oil-free } \\
\text { vs } \\
30 \mathrm{~g} \mathrm{Fish} \\
\text { oil/kg }\end{array}$ & $\begin{array}{c}15 \mathrm{~g} \mathrm{Fish} \\
\text { oil/kg } \\
\text { vs } \\
30 \mathrm{~g} \mathrm{Fish} \\
\mathrm{oil} / \mathrm{kg}\end{array}$ \\
\hline \multicolumn{13}{|c|}{ Serum lipids ( $\mu \mathrm{mol} / \mathrm{dl})$} \\
\hline Triacylglycerol & $395 \pm 53^{c}$ & $156 \pm 18^{\mathrm{b}}$ & $163 \pm 8^{b}$ & $124 \pm 19^{b}$ & $122 \pm 11^{b}$ & $77.3 \pm 10.3^{a}$ & $<0.01$ & $<0.01$ & $<0.01$ & - & - & - \\
\hline Cholesterol & $337 \pm 15^{d}$ & $280 \pm 15^{b, c}$ & $248 \pm 13^{b}$ & $248 \pm 11^{b}$ & $297 \pm 10^{c}$ & $166 \pm 8^{a}$ & $<0.01$ & $<0.01$ & $<0.01$ & - & - & - \\
\hline Phospholipid & $359 \pm 19$ & $269 \pm 15$ & $268 \pm 14$ & $241 \pm 12$ & $249 \pm 20$ & $183 \pm 8$ & $<0.01$ & $<0.01$ & ns & $<0.01$ & $<0.01$ & ns \\
\hline \multicolumn{13}{|c|}{ Serum lignans ( $\mathrm{nmol} / \mathrm{dl})$} \\
\hline Sesamin & - & $9.73 \pm 2.17^{b}$ & - & $3.35 \pm 0.63^{\mathrm{a}}$ & - & $3.20 \pm 0.69^{a}$ & - & - & - & - & - & - \\
\hline Episesamin & - & $104 \pm 14^{b}$ & - & $46.1 \pm 9.6^{a}$ & - & $30.7 \pm 5.2^{\mathrm{a}}$ & - & - & - & - & - & - \\
\hline \multicolumn{13}{|c|}{ Liver lignans (nmol/g) } \\
\hline & - & $4.87 \pm 0.53$ & - & $3.74 \pm 0.83$ & - & $3.59 \pm 0.79$ & - & - & - & - & - & - \\
\hline & - & $13.1 \pm 1.5$ & - & $10.6 \pm 2.3$ & - & $10.9 \pm 2.1$ & - & - & - & - & - & - \\
\hline \multicolumn{13}{|c|}{ Liver $\mathrm{n}-3$ fatty acids $(\mu \mathrm{mol} / \mathrm{g})$} \\
\hline EPA & $0.24 \pm 0.05$ & $0.21 \pm 0.04$ & $5.12 \pm 0.16$ & $4.68 \pm 0.69$ & $7.81 \pm 0.43$ & $7.94 \pm 0.55$ & $<0.01$ & ns & ns & $<0.01$ & $<0.01$ & $<0.01$ \\
\hline DHA & $3.64 \pm 0.18^{a}$ & $5.46 \pm 0.27^{b}$ & $15.9 \pm 0.3^{c}$ & $16.4 \pm 1.2^{c}$ & $21.0 \pm 1.2^{\mathrm{d}}$ & $32.4 \pm 1.9^{\mathrm{e}}$ & $<0.01$ & $<0.01$ & $<0.01$ & & & \\
\hline
\end{tabular}

Values are the means \pm SE of 7 rats. a,b,c Means in a row with superscripts without a common letter differ, $p \leq 0.05$. ns: Not significant.

meters were not observed in rats give diets containing $15 \mathrm{~g}$ fish oil $/ \mathrm{kg}$. Two-way ANOVA indicated that both sesamin and fish oil were effective in reducing serum concentrations of phospholipid. Subsequent post-hoc analysis revealed that there was no significant dose-dependent effect of fish oil in affecting this value.

As the sesamin preparation employed in the current study contained sesamin and episesamin at an equimolar ratio, these compounds were detected in the serum of rats fed sesamin. As has been demonstrated in previous studies, ${ }^{(6,7)}$ the serum and liver concentrations of episesamin greatly exceeded those of sesamin in all groups of rats; i.e., the concentrations of the former were 9.6-13.8 and 2.7-3.0 times higher than those of the latter, for the serum and liver, respectively. Fish oil at 15 and $30 \mathrm{~g} / \mathrm{kg}$ levels significantly lowered the serum concentrations of these lignans to similar values. Changes due to the differences in dietary levels of fish oil were not detected in both episesamin and sesamin concentrations in the liver.

Fish oil feeding strongly increased hepatic concentrations of EPA and DHA in dose-dependent manner. Sesamin did not affect the concentrations of EPA among rats fed diets containing different amounts of fish oil. However, the lignan significantly increased hepatic concentrations of DHA in rats fed a fish oil-free and $3.0 \%$ fish oil diets, but not in the animals fed a $1.5 \%$ fish oil diet. 


\section{Discussion}

We previously observed that fish oil, and EPA and DHA ethyl esters added at experimental diets at the levels of 80 and $20 \mathrm{~g} / \mathrm{kg}$, respectively, strongly enhanced the physiological activity of sesamin in increasing the activity of many enzymes involved in hepatic fatty acid oxidation in rats. ${ }^{(6,7)}$ A synergistic increase in mRNA levels caused by a diet simultaneously containing fish oil or n-3 fatty acid ethyl esters and sesamin was noted in peroxisomal but not in mitochondrial enzymes. Therefore, it was suggested that the synergistic increase in the activity levels of enzymes involved in hepatic fatty acid oxidation caused by the diet containing these dietary factors in combination was primarily due to the up-regulation of enzymes involved in peroxisomal fatty acid oxidation. $^{(6,7)}$ In the present study, we confirmed that fish oil strongly enhanced the physiological activity of sesamin in increasing the activity of many enzymes involved in hepatic fatty acid oxidation and mRNA levels of peroxisomal proteins, despite dietary levels much lower than the level employed in the previous study. ${ }^{(6)}$ The magnitudes of the synergistic increase were comparable between those caused by the diet containing either 15 or $30 \mathrm{~g}$ fish oil $/ \mathrm{kg}$, and $2 \mathrm{~g}$ sesamin $/ \mathrm{kg}$ in combination, and appeared comparable to those caused by a diet simultaneously containing $80 \mathrm{~g}$ fish oil $/ \mathrm{kg}$ and $2 \mathrm{~g}$ sesamin $/ \mathrm{kg}$ reported previously ${ }^{(6)}$; therefore, the dose-dependent effect of fish oil on this synergism with sesamin as a counterpart appeared indistinguishable between dietary levels from 15 to $80 \mathrm{~g} / \mathrm{kg}$. In this situation, fish oil increased the activity and mRNA levels of mitochondrial and peroxisomal enzymes involved in fatty acid oxidation dosedependently when it was added to sesamin-free diets. This implies that fish oil, apart from its activity to increase hepatic fatty acid oxidation, acts as a co-activator of sesamin to enhance hepatic fatty acid oxidation. Fish oil at a dietary level as low as $15 \mathrm{~g} / \mathrm{kg}$ appeared sufficient to cause a maximal effect in enhancing the physiological activity of sesamin to increase hepatic fatty acid oxidation. EPA and DHA can mimic the physiological activity of fish oil to cause this effect, ${ }^{(7)}$ and a dietary level of these n-3 fatty acids at $6 \mathrm{~g} / \mathrm{kg}$ is considered sufficient to lead maximal synergistic effect, taking in account the sum of the quantities of these $n-3$ fatty acids contained in fish oil employed in the present study ( $40 \mathrm{~g} / 100 \mathrm{~g}$ fatty acids). This dietary level of $\mathrm{n}-3$ fatty acids is still considered about 2 times higher than the level expected in the typical Japanese diet; however, our current study raised the possibility that n-3 fatty acids lower than $6 \mathrm{~g} / \mathrm{kg}$ diet would be effective to cause a synergistic increase in hepatic fatty acid oxidation with sesamin as a counterpart. This is because fish oil at 15 and $30 \mathrm{~g} / \mathrm{kg}$ were equally effective to stimulate the physiological activity of sesamin to increase hepatic fatty acid oxidation. At present, the minimal dietary level of fish oil causing this effect is not known.

The mechanism by which $\mathrm{n}-3$ fatty acids and sesamin cause a synergistic increase in the gene expression of peroxisomal enzymes is not clear. Sesamin is not an antioxidant in vitro, but is metabolized to compounds having antioxidation propensity; ${ }^{(13)}$ therefore, there is the possibility that sesamin when given to animals in combination with $n-3$ fatty acids increases the retention in tissue of n-3 fatty acids through the prevention of oxidative degradation. This consequence may cause an exaggerated increase in hepatic fatty acid oxidation because n-3 fatty acids have activity to increase hepatic fatty acid oxidation. Although sesamin was not effective in modulating hepatic EPA concentration, this compound actually increased the DHA concentration in rats fed a diet free of fish oil and a diet containing 3.0\% fish oil. However, the lignan failed to affect DHA concentration in rats given a diet containing $1.5 \%$ fish oil. Apparently, there was no clear-cut relationship between hepatic fatty acid oxidation and concentration of n-3 fatty acid in the present study.

Alternatively, there is the possibility that n-3 fatty acids modulate the metabolism of sesamin and hence cause changes in hepatic fatty acid oxidation. As the sesamin preparation employed in this study is a 1:1 mixture of sesamin and episesamin, these compounds are detected in serum. It has been demonstrated that episesamin is much more effective than sesamin in increasing hepatic fatty acid oxidation; ${ }^{(3,14)}$ therefore, alteration in the liver concentration of the lignan, especially episesamin, may affect hepatic fatty acid oxidation. However, fish oil did not affect hepatic concentrations of either sesamin or episesamin. There is the possibility that some metabolite(s) of sesamin or episesamin rather than the original compound is the actual inducer of hepatic fatty acid oxidation; ${ }^{(13)}$ therefore, the possibility cannot be disregarded that n-3 fatty acids increase the conversion of the lignan to generate a compound capable of causing a marked increase in hepatic fatty acid oxidation. Fish oil decreased the serum concentration of both sesamin and episesamin. As both sesamin and episesamin are hydrophobic compounds, it is plausible that they are incorporated into serum lipoproteins and transported in the circulation. ${ }^{(15)}$ Therefore, decreases of serum lignan concentration by fish oil may represent the consequence of the reduction of serum concentrations of lipoproteins. Consistent with this consideration, changes in serum lipid levels generally paralleled those in lignan concentrations in the present study.

The potential role of the peroxisome proliferator activated receptor (PPAR), a member of nuclear receptor superfamily in regulating lipid metabolism has been well demonstrated. ${ }^{(16,17)}$ Various types of PPAR ( $\alpha, \gamma 1, \gamma 2$ and $\delta$ ) have been identified in rodents and humans. PPAR $\alpha$ is highly expressed in liver and may play a crucial role in regulating lipid metabolism in this tissue. A wide range of natural and synthetic compounds can function as PPAR ligands. The natural agonists for PPAR $\alpha$ include fatty acids and fatty acid derivates, mainly eicosanoids. Previous information ${ }^{(2,3)}$ suggests that sesamin is also a natural ligand to activate PPAR $\alpha$. With respect to the synthetic ligands, fibrate as lipid-lowering drugs function as PPAR $\alpha$ agonists. PPAR $\alpha$ is activated by the ligand and heterodimerized with the retinoid-X receptor (RXR) then bind to specific DNA sequences, known as peroxisome proliferator response elements (PPREs), in the promotor region of target genes, thereby acting as a transcriptional regulator. Enzymes involved in fatty acid oxidation are targeted by PPAR $\alpha$. Genes of peroxisomal acyl-CoA oxidase 1 and bifunctional enzymes involved in fatty acid oxidation were first identified as targets to be activated by PPAR $\alpha .^{(18,19)}$ Later studies, ${ }^{(20-22)}$ however, showed that PPAR $\alpha$ up-regulates the gene expression not only of peroxisomal proteins but also of proteins associated with organelles other than peroxisomes and involved in lipid metabolism. In this study, as has also been observed in previous studies, ${ }^{(6,7)}$ enhanced increases in mRNA expression in animals on diets containing both sesamin and fish oil were noted for the peroxisomal enzymes involved in fatty acid oxidation and a membrane protein (peroxin-11 $\alpha$ ) associated with peroxisomes, but not in enzymes associated with mitochondria and microsomal cytochrome P-450 4a1. Therefore, our current observation indicates the existence of a mechanism independent of PPAR $\alpha$ to specifically induce the gene expression of peroxisomal proteins.

In conclusion, we showed that low dietary levels (15 and $30 \mathrm{~g} / \mathrm{kg}$ ) of fish oil greatly enhanced the physiological activity of sesamin to increase hepatic fatty acid oxidation, primarily through the upregulation of peroxisomal fatty acid oxidation enzymes. The extent of this augmentation was indistinguishable between diets containing 15 and $30 \mathrm{~g}$ fish oil $/ \mathrm{kg}$ and sesamin in combination, and appeared comparable to that observed previously with a diet containing $80 \mathrm{~g}$ fish oil $/ \mathrm{kg}^{(6)}$ or containing $20 \mathrm{~g}$ EPA or DHA $/ \mathrm{kg}$ in the form of ethyl ester ${ }^{(7)}$ and sesamin in combination. It was considered that fish oil at dietary levels observable in the usual Japanese human diets can stimulate the physiological activity of sesamin to enhance hepatic fatty acid oxidation. 


\section{Acknowledgments}

This study was supported by a grant-in-aid for scientific research (Scientific Research C, no. 22580143) from the Ministry of Education, Culture, Sports, Science and Technology and a grant from the Ministry of Agriculture, Forestry and Fisheries (MAFF) research project, "Development of evaluation and

\section{References}

1 Fukuda Y, Nagata M, Osawa T, Namiki M. Contribution of lignan analogues to antioxidative activity of refined unroasted sesame seed oil. J Am Oil Chem Soc 1986; 63: 1027-1031.

2 Ashakumary L, Rouyer I, Takahashi Y, et al. Sesamin, a sesame lignan, is a potent inducer of hepatic fatty acid oxidation in the rat. Metabolism 1999; 48: 1303-1313.

3 Kushiro M, Masaoka T, Hageshita S, Takahashi Y, Ide T, Sugano M. Comparative effect of sesamin and episesamin on the activity and gene expression of enzymes in fatty acid oxidation and synthesis in rat liver. $J$ Nutr Biochem 2002; 13: 289-295.

4 Ide T, Kobayashi H, Ashakumary L, et al. Comparative effects of perilla and fish oils on the activity and gene expression of fatty acid oxidation enzymes in rat liver. Biochim Biophys Acta 2000; 1485: 23-35.

5 Ren B, Thelen AP, Peters JM, Gonzalez FJ, Jump DB. Polyunsaturated fatty acid suppression of hepatic fatty acid synthase and S14 gene expression does not require peroxisome proliferator-activated receptor $\alpha$. J Biol Chem 1997; 272: $26827-26832$.

6 Ide T, Hong DD, Ranasinghe P, Takahashi Y, Kushiro M, Sugano M. Interaction of dietary fat types and sesamin on hepatic fatty acid oxidation in rats. Biochim Biophys Acta 2004; 1682: 80-91.

7 Arachchige PG, Takahashi Y, Ide T. Dietary sesamin and docosahexaenoic and eicosapentaenoic acids synergistically increase the gene expression of enzymes involved in hepatic peroxisomal fatty acid oxidation in rats. Metabolism 2006; 55: 381-390.

8 Reeves PG, Nielsen FH, Fahey GC Jr. AIN-93 purified diets for laboratory rodents: final report of the American Institute of Nutrition ad hoc writing committee on the reformulation of the AIN-76A rodent diet. J Nutr 1993; 123: 1939-1951.

9 Lazarow PB, De Duve C. A fatty acyl-CoA oxidizing system in rat liver peroxisomes; enhancement by clofibrate, a hypolipidemic drug. Proc Natl Acad Sci USA 1976; 73: 2043-2046.

10 Ide T. Interaction of fish oil and conjugated linoleic acid in affecting hepatic activity of lipogenic enzymes and gene expression in liver and adipose tissue. Diabetes 2005; 54: 412-423.

11 Lim JS, Adachi Y, Takahashi Y, Ide T. Comparative analysis of sesame management methods for supply of safe, reliable and functional food and farm produce".

\section{Conflict of Interest}

No potential conflicts of interest were disclosed.

lignans (sesamin and sesamolin) in affecting hepatic fatty acid metabolism in rats. Br J Nutr 2007; 97: 85-95.

12 Schrader M, Reuber BE, Morrell JC, et al. Expression of PEX11 $\beta$ mediates peroxisome proliferation in the absence of extracellular stimuli. J Biol Chem 1998; 273: 29607-29614.

13 Nakai M, Harada M, Nakahara K, et al. Novel antioxidative metabolites in rat liver with ingested sesamin. J Agric Food Chem 2003; 51: 1666-16670.

14 Ide T, Lim JS, Odbayar TO, Nakashima Y. Comparative study of sesame lignans (sesamin, episesamin and sesamolin) affecting gene expression profile and fatty acid oxidation in rat liver. J Nutr Sci Vitaminol (Tokyo) 2009; 55: $31-43$.

15 Umeda-Sawada R, Ogawa M, Igarashi O. The metabolism and distribution of sesame lignans (sesamin and episesamin) in rats. Lipids 1999; 34: 633-637.

16 Fruchart JC. Peroxisome proliferator-activated receptor- $\alpha(\operatorname{PPAR} \alpha)$ : at the crossroads of obesity, diabetes and cardiovascular disease. Atherosclerosis 2009; 205: 1-8.

17 Pyper SR, Viswakarma N, Yu S, Reddy JK. PPAR $\alpha$ : energy combustion, hypolipidemia, inflammation and cancer. Nucl Recept Signal 2010; 8: e002.

18 Bardot O, Aldridge TC, Latruffe N, Green S. PPAR-RXR heterodimer activates a peroxisome proliferator response element upstream of the bifunctional enzyme gene. Biochem Biophys Res Commun 1993; 192: 37-45.

19 Marcus SL, Miyata KS, Zhang B, Subramani S, Rachubinski RA, Capone JP. Diverse peroxisome proliferator-activated receptors bind to the peroxisome proliferator-responsive elements of the rat hydratase/dehydrogenase and fatty acyl-CoA oxidase genes but differentially induce expression. Proc Natl Acad Sci USA 1993; 90: 5723-5727.

20 Gulick T, Cresci S, Caira T, Moore DD, Kelly DP. The peroxisome proliferator-activated receptor regulates mitochondrial fatty acid oxidative enzyme gene expression. Proc Natl Acad Sci USA 1994; 91: 11012-11016.

21 Aldridge TC, Tugwood JD, Green S. Identification and characterization of DNA elements implicated in the regulation of CYP4A1 transcription. Biochem $J$ 1995; 306: 473-479.

22 Aoyama T, Peters JM, Iritani N, et al. Altered constitutive expression of fatty acid-metabolizing enzymes in mice lacking the peroxisome proliferatoractivated receptor $\alpha(\mathrm{PPAR} \alpha)$. J Biol Chem 1998; 273: 5678-5684. 